\title{
Directing Traffic at the Crossroads of Criminal Justice and Mental Health: Conditional SENTENCING AFTER THE JUDGMENT IN KNOBLAUCH
}

\author{
JULIAN V. ROBERTS AND SIMON VERDUN-JONES“
}

The issue of conditional sentencing in relation to mentally disordered offenders was recently addressed by the Supreme Court of Canada in R. v. Knoblauch. This article examines the context in which the Knoblauch decision was made by reviewing the incidence of mental disorders in correctional populations and the criminal justice system's response. The authors explore Knoblauch's implications on the conditional sentencing regime as a whole and its use as a sentencing tool for dealing with mentally disordered offenders.
La Cour, suprème du Canada s'est penchèe sur la question de l'ordonnance de sursis en ce qui concerne les délinquants atteints de troubles mentaux dans l'affaire R. contre Knoblauch. Cet article examine le contexte dans lequel la décision Knoblauch a été prise en réexaminan / incidence de troubles mentaux chez la population pénitentiaire ef la réaction du système de justice pénale. Les auteurs explorent les implications de la décision Knoblauch sur le régime de condamnations conditionnelles dans son ensemble et son utilisation comme outil pour traiter avec les délinquants atteints de troubles mentaux.

\section{TABLE OF CONTENTS}

I. INTRODUCTION $\ldots \ldots \ldots \ldots \ldots \ldots \ldots \ldots \ldots$
A. INCIDENCE OF MENTAL DISORDERS IN

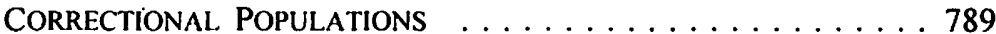
B. CRIMINAL JUSTICE RESPONSE TO MENTALLY
DISORDERED OFFENDERS . . . . . . . . . . . . . . 790
C. THE KNOBLAUCH CASE . . . . . . . . . . . . . . . . . . 792

II. IMPLICATIONS FOR THE CONDITIONAL SENTENCING REGIME . . . . 794

A. TEST OF DANGER to THE COMMUNITY . . . . . . . . . 795

B. CAN CONFINEMENT IN A LOCKED PSYCHIATRIC

FACILITY BE A CONDITION OF A CONDITIONAL

SENTENCE ORDER? . . . . . . . . . . . . . . . . 803

C. DEFINING THE COMMUNITY IN A

COMMUNITY-BASED SANCTION .............. 805

D. ROLE OF RESTORATIVE ELEMENT IN SENTENCING . . . . . . . . 807

E. EFFECTS OF KNOBLAUCH ON TRIAL JUDGES ......... 808

\section{INTRODUCTION}

The recent judgment of the Supreme Court of Canada in $R$. v. Knoblauch' addresses problems that have long existed in the sentencing process, as well as some new issues pertaining to the conditional sentencing regime. Knoblauch confronted the Court with an

University of Ottawa.

.. Simon Fraser University. The authors are very grateful to the following individuals for helpful comments about the subject of this article: Judge David Cole. Professor Allan Manson, and Professor Patrick Healy.

I R. Knoblauch, [2000] 2 S.C.R. 780, [2000] S.C.J. No. 59, online: QL (SCJ) [hereinafter Knoblauch cited to S.C.J.]. 
unusual fact situation, and the Court's response was to break ground with respect to the nature, ambit, and methodology of the conditional sentence. The position of the majority also opens new avenues with respect to sentencing mentally disordered offenders. In this commentary, we discuss some implications of the decision for the conditional sentencing regime in general, and in particular its potential utility as a sentencing tool for mentally disordered offenders. First of all, however, it is necessary to examine the context within which sentencing decisions are made in relation to mentally disordered offenders in Canada.?

\section{A. InCidence of Mental Disorders in Correctional. Populations}

There is little doubt that if one examines the inmate populations of either federal or provincial/territorial correctional institutions in Canada, one will inexorably find significant numbers of individuals who have - at some point in their lifetime - suffered from a major mental disorder. ${ }^{3}$ The lifetime incidence of major mental disorders is considerably greater among incarcerated offenders than among the general population. It is noteworthy that this proposition holds true for both provincial/territorial inmates (those with sentences of less than two years) and federal inmates (those with sentences of more than two years).

One study of provincial inmates found that the lifetime incidence of schizophrenia was 2.2 percent compared to 0.4 percent in the general population. The equivalent rates for affective disorders (manic episode, major depression, dysthymia) were 22.8 percent for inmates compared to 12 percent of the population at large. It is striking that when all forms of mental disorder (including personality disorders and substance abuse disorders) were included, the lifetime prevalence rate for inmates was 91.7 percent rather than 43.7 percent for the population at large. Given the nature of these findings, and the fact that the majority of inmates were serving relatively short sentences, the authors wryly concluded that

[t]he present system of numerous brief sentences, for often minor offenses by a population that is socially and psychiatrically disadvantaged, in which there is a high rate of repeat offenses, and to which little or no treatment or rehabilitation is given. appears to serve no one very well. Society bears the cost but derives little benefit; the individuals fail to benefit from the experience, and there is little evidence that the experience serves to modify subsequent behavior. ${ }^{4}$ Sense of Sentencing (Toronto: University of Toronto Press, 1999) 160.

$3 \quad$ R.C. Bland et al., "Psychiatric Disorders in the Population and in Prisoners" (1998) 21 Int'l J. L. \& Psy. 273; J. Brink, D. Doherty \& A. Boer, "Mental Disorder in Federal Offenders - A Canadian Prevalence Study” (2001) 24 Int'l J. L. \& Psy. 339; L.L. Motiuk \& F.J. Porporino, The Prevalence. Nature and Severity of Mental Health Problems Among Federal Inmates in Canadian Penitentiaries (Ottawa: Report No. 24, Research and Statistics Branch, Correctional Service of Canada, 1991); R. Roesch, "Mental Health Interventions in Jails" in G. Davis et al. eds., Psychology, Law and Criminal Justice (New York: Walter de Gruyter, 1995) 520.

4.C. Bland et al., ibid. at 278. 
For those inmates who fall within the jurisdiction of the Correctional Service of Canada, the rates of serious mental disorder are even more striking. For example, in a random sample of 2000 male prisoners, Motiuk and Proporino found that the lifetime risk of a psychotic episode was as high as 7.7 percent. ${ }^{5}$ Furthermore, Brink, Doherty and Boer found that 84.2 percent of a sample of 267 male inmates entering the federal corrections system in 1999 had a lifetime diagnosis of some form of mental disorder. It is noteworthy that as many as 8.5 percent of the sample had a combined current and lifetime diagnosis of schizophrenia or other psychotic disorder (as compared with only 0.5 percent of the population at large), with 3.5 percent experiencing current symptoms. Furthermore, 30.2 percent of the federal inmates had a combined current and lifetime diagnosis of a mood disorder (e.g., depression, bipolar disorder) - compared with just 8.7 percent in the general population. Finally, it was found that 75.7 percent of these inmates had a lifetime diagnosis of a substance use disorder, and 18.3 percent suffered from an anxiety disorder of some kind. Brink and his colleagues conclude that "the amendments to the Canadian Criminal Code, introduced in 1992 and intended to divert mentally ill offenders deemed not criminally responsible by reason of mental disorder, to mental health care rather than prison facilities, have not resulted in noticeable differences."

\section{B. Criminal Justice Response to Mentally Disordered OfFenders}

The shockingly high number of seriously mentally disordered offenders who are incarcerated in correctional institutions in Canada reflects - to some extent at least the absence of a viable sentencing option that is specifically designed to ensure that such individuals are sent to mental health facilities rather than to prisons. In contrast, in England and Wales, courts have the option to impose a hospital order upon a convicted mentally disordered offender who would otherwise be facing imprisonment. ${ }^{7}$ The result of making such an order is that the offender enters a mental health facility rather than a prison, and once in the mental health system, he or she may not be transferred back into the corrections system: in this sense, the hospital order constitutes a "one-way street." Public protection is ensured through the imposition of a "restriction order" that generally implies that the offender may only be released by the order of a specialized mental health review tribunal.

Although there have been some significant changes to this system in recent years, a seriously mentally disordered offender in England and Wales will be treated in a mental

The authors indicate that, by "psychotic episode," they mean to refer to schizophrenia or schizophreniform psychosis. See Motiuk \& Porporino, supra note 3.

" Brink, Dolserty \& Boer, supra note 3 at 354 . The authors are referring to the amendments to the Criminal Code that were introduced with the enactment of Bill C-30 (199I). These amendments are generally considered to have rendered it more "aturactive" for counsel to raise the defence of NCRMD under s. 16 of the Code. See, S. Verdun-Jones, "Making the Mental Disorder Defence a More Attractive Option for Defendants in a Criminal Trial: Recent Legal Developments in Canada" in D. Eaves, J.R.P. Ogloff \& R. Roesch, eds., Mental Disorders and the Criminal Code: Legal Background and Contemporary Perspectives (Burnaby, B.C.: Mental Health, Law, and Policy Institute. Simon Fraser University, 2000) 39.

See S.N. Verdun-Jones, "Sentencing the Partly Mad and the Partly Bad: The Case of the Hospital Order in England and Wales" (1989) 12 Int'I J. L. \& Psy. 1. 
health facility and released directly back into the community, according to the status of his or her mental health. ${ }^{8}$ The effective implementation of a hospital-order system of this type does require that there be a range of mental health facilities that can accommodate differing levels of security requirements, as well as adequate community follow-up. In other words, the use of the hospital order in England and Wales results in the expenditure of a considerable amount of resources, which are drawn from the public health system (the National Health Service) rather than from correctional resources. However, it appears that this is a price that the authorities in England and Wales have been willing to pay in return for the humane sentencing alternative that the hospital order provides for offenders with serious mental disorders.

Regrettably, Canadian courts do not enjoy the benefit of a sentencing option of the type offered by the hospital order in England and Wales. ${ }^{9}$ There are some unproclaimed provisions of the Criminal Code that do indeed provide for the implementation of socalled "hospital orders"; however, these (proposed) orders bear little - or no resemblance to the sentencing option that is available to the courts in England and Wales. ${ }^{10}$ The unproclaimed Criminal Code provisions would have made it possible for a trial judge to order that an offender, who had already been sentenced to a term of imprisonment, should receive treatment in a hospital for a period not exceeding sixty days. The wording of the proposed s. 747.1(1) makes it crystal clear that the Canadian-style hospital order would be targeted solely at offenders suffering from an acute mental disorder and that it would function solely as a preliminary step on the road towards ultimate incarceration within the corrections system:

\begin{abstract}
A court may order that an offender be detained in a treatment facility as the initial part of a sentence of imprisonment where it finds, at the time of sentencing, that the offender is suffering from a mental disorder in an acute phase and the court is satisfied, on the basis of an assessment report and any other evidence, that immediate treatment of the mental disorder is urgently required to prevent further significant deterioration of the mental or physical health of the offender, or to prevent the offender from causing serious bodily harm to any person. ${ }^{\prime \prime}$
\end{abstract}

Essentially, the Criminal Code contains no specific mechanism (either proclaimed or unproclaimed) by means of which a Canadian court may order that a mentally disordered offender shall serve the whole of an institutional sentence in a psychiatric facility rather than in a prison. Given the appallingly high numbers of seriously mentally disordered

In certain circumstances, individuals who are found to be suffering from "psychopathic disorder" may now be transferred from a hospital to prison. However, to date, this significant change in the hospitalorder regime has not been applied to offenders suffering from a "mental disorder." See N. Eastman \& J. Peay, "Sentencing Psychopaths: Is the 'Hospital and Limitation Direction' an Ill-Considered Hybrid?" (1998) Crim. L.R. 93.

" Nor is there any formal mechanism to mitigate the severity of a sentence to reflect the reduced culpability arising from the offender's mental disorder.

11. See E.A. Tollefson \& B. Starkman, Mental Disorder in Criminal Proceedings (Toronto: Carswell. 1993) at 143. In the Knoblauch case, supra note I at paras. 44-45, Madam Justice Arbour (for the majority) strongly emphasized the limited nature of the proposed hospital order provisions in the Criminal Code.

$" \quad$ See S.C. 1995, c. 22, s. 6. 
individuals who are currently serving time in correctional facilities (where their mental health condition is unlikely to improve and may well deteriorate) it is perhaps inevitable that the courts have been searching for a method of diverting such individuals to the mental health system. The judgment of the majority of the Supreme Court of Canada in the Knoblauch case suggests that the conditional sentence may well be the mechanism for which the courts have been searching.

\section{The KNoblauch CaSe}

The facts giving rise to Knoblauch's appeal to the Supreme Court of Canada are the following. The appellant plead guilty to unlawful possession of an explosive substance contrary to then s. 100(12) of the Criminal Code and to unlawful possession of a weapon for a purpose dangerous to the public peace, contrary to then s. 87 of the Code. In addition, there was a prior conviction for the offence of possession of a weapon for a purpose dangerous to the public peace for which he had been sentenced to a conditional discharge and placed on probation.

The background to these offences was a lengthy history of mental illness, consisting of "longstanding deeply ingrained personality difficulties with features of obsessive compulsiveness and depression" and "fantasies about violent matters." 12 In addition, the police found the appellant to be in possession of a substantial arsenal capable of causing great harm to the public and damage to property. After hearing extensive evidence from expert witnesses, the trial judge imposed a conditional sentence of two years less a day to be followed by three years of probation. The offender was required to spend the period of the conditional sentence in a secure psychiatric treatment unit, unless and until a consensus of psychiatric professionals made a decision to transfer him from the locked unit.

On appeal by the Crown, the Alberta Court of Appeal set aside the conditional sentence and substituted a period of incarceration in a provincial prison, to be followed by a threeyear term of probation. ${ }^{13}$ The majority decision of the Supreme Court of Canada was to uphold the sentence originally imposed by the trial judge. Dissenting judgments were written by Bastarache J. (L'Heureux-Dubé and Gonthier JJ. concurring) and lacobucci, J.

The fact that the majority upheld the imposition of a conditional sentence in this case is evidence of the rapid evolution of the new sanction, which was originally intended to divert less serious offenders from provincial jails to serve their terms of custody in the community. It is barely four years since this alternative to imprisonment was created. How has this evolution come about? The major engine for change has been the Court's unanimous judgment in $R$. v. Proulx. ${ }^{14}$ That decision made it clear that the conditional

The Alberta Court of Appeal varied the conditions of the term of probation. The offender was to be reside in "such place as is specified by his attending psychiatrist. Dr. Tweddle, or by such other psychiatrist as may supervise his treatment." $R$. v. Knoblauch, [1999] A.J. No. 377 at para. 30, online: QL (AJ).

14 [2000] I S.C.R. 61 [hereinafter Proulx]. 
sentence has a very broad ambit and that no offences are ruled out of consideration as long as the statutory criteria established in $\mathbf{s}$. 742.1 have been satisfied. The Proulx judgment also contained a ringing endorsement of the principle of deference to the trial judge: "a court of appeal should only intervene to vary a sentence imposed at trial if the sentence is demonstrably unfit." but this principle may have guided the majority's position with respect to this decision.

\section{DESERT VERSUS DANGEROUSNESS IN SENTENCING}

The Knoblauch case raises a central question which pervades the sentencing process, and which remains unresolved after centuries of debate in Canada and other jurisdictions: should we punish offenders for the crimes of which they have been convicted or for the crimes that they are likely to commit? This is nothing less than the age-old conflict between the utilitarian and the just deserts sentencing philosophies. The statutory framework created in 1996 contains at its heart an endorsement of desert-based sentencing. Section 718.1 of the Criminal Code identifies proportionality as the fundamental principle of sentencing. But the fundamental purpose of sentencing also identifies several utilitarian objectives, including specific deterrence. Thus sentencing in Canada embraces both utilitarian and retributive traditions. However, by designating proportionality as the "fundamental" principle of sentencing, Parliament seems to have privileged the retributive sentencing perspective when it approved the statement of purpose and principle now found in Part XXIII of the Code.

Sentencing scholars will be divided in their response to this case. The reason for this is that the threat to the community springs not from the seriousness of the offence of conviction, and still less from the offender's previous conviction (which resulted in the imposition of a conditional discharge), but rather on the court's predictions of his future behaviour. ${ }^{16}$ From a just deserts perspective, then, a long custodial term is unjustifiable. The imposition of a lengthy sentence is justified solely on the grounds of crime prevention. Imposing a severe sentence of imprisonment on such an offender because he is considered to be likely to commit serious crimes in the future runs the risk of violating the principle of proportionality in sentencing. Desert-based sentencers will, therefore, feel uneasy with the imposition of a harsh sentence; utilitarians, on the other hand, will argue that it is clearly necessary to prevent future harm. The majority judgment acknowledges this issue: "There is no mechanism in criminal law to remove dangerous people from

16. The only physical injury caused by the offender over the decade in question was to his own finger while assembling a detonator. Increasing the length of a determinate sentence of imprisonment in order to protect the public from the perceived dangerousness of a mentally disordered offender would clearly infringe the proportionality principle. See H. Holley, J. Arboleda-Flórez \& A. Crisanti, "Do Forensic Offenders Receive Harsher Sentences?" (1998) 2 I Int'] J. L. \& Psy. 43; J. Peay, "Surviving psychiatry in an era of 'popular punitiveness"' (2000) 101 Acta Psychiatrica Scandinavica 72; S.N. Verdun-Jones, "Forensic psychiatry, ethics and protective sentencing: what are the limits of psychiatric participation in the criminal justice process?" (2000) 101 Acta Psychiatrica Scandinavica 77. 
society merely in anticipation of the harm that they may cause. The limit of the reach of the criminal sanction is to address what offenders have done." 17

However, civil commitment may legitimately be used as an anticipatory mechanism for imposing restraints on the freedom of an acutely mentally ill person who is considered to be dangerous to others. ${ }^{18}$ Civil commitment may occur before the individual concerned has actually committed an act that constitutes a danger to the community. It is highly significant that the accused in the Knoblauch case had been "certified" (civilly committed) under the Alberta Mental Health $A c t^{19}$ immediately after his arrest and had remained in residential psychiatric care for the five months immediately preceding his appearance before the provincial court judge for sentencing. ${ }^{20}$ In this sense, the accused clearly found himself "at the often ambiguous crossroads between the criminal justice and the mental health care systems."21

Civil commitment is undoubtedly imposed on a mentally disordered person for the purpose of treatment, not punishment. However, Knoblauch had entered a guilty plea to the charges against him, and there was no question of his being found "Not Criminally Responsible on Account of Mental Disorder" under the terms of s. 16 of the Criminal Code. Therefore, although he had been committed to the mental health system for treatment, he was liable to punishment within the framework of the criminal justice system. In England and Wales, the accused would have been a strong candidate for a hospital order. To pursue the hypothetical argument a little further, if a hospital order had been imposed, Knoblauch would have been sent on a one-way journey to a mental health facility, and a restriction order would have ensured that he would not be released until his mental health condition had improved to the point where he no longer constituted a potential danger to others. The provincial court judge in Alberta, however, did not have the benefit of being able to consider such a sentencing option. Instead, the Court attempted - within the existing parameters of the sentencing provisions of the Criminal Code - to fashion a sentence that reflected the need to punish the accused, while simultaneously keeping him within a treatment setting in the mental health system.

\section{ImPlications for the CONDitional SENTENCING REgime}

In Knoblauch, the Supreme Court of Canada split on three critical questions. First, how should the question of danger to the community be resolved as a court decides whether a conditional sentence is an appropriate sanction? Second, do the optional conditions that may be attached to a conditional sentence encompass ordering the offender to spend the sentence in a locked psychiatric facility? Third, can residence in a secure psychiatric institution be considered a "community" sanction that differs from a term in a correctional institution? As will be seen, the three questions are highly interrelated. For example, only

17

1.) S.A. 1988. c. M-13.1.

211 Knoblauch, supra note 1 at paras. 8-9.

2 lbid. at para. I, Arbour J. Irwin Law. 2001) at 384. 65.

Knoblauch, supra note 1 at para. 16. See generally A. Manson, The Law of Sentencing (Toronto:

G. Høyer, "On the Justification for Civil Commitment" (2000) 101 Acta Psychiatrica Scandinavica 
if the question of danger to the community includes a consideration of the conditions that would be imposed does the question of whether a given condition is appropriate arise at all. The last question of course takes us to consider the very essence of a conditional sentence of imprisonment, and in particular to resolve the question of how it differs from a term of conventional custody in a correctional institution.

\section{A. Test of Danger to ThE Community}

Whether the majority was correct to conclude that this specific appellant would not represent a threat to the community will not detain us here; there is, however, an important lesson of general application with respect to the methodology employed to determine whether an offender constitutes a threat.

The central disagreement between the majority and the primary dissenting judgment concerns the test for dangerousness that should be applied in determining the suitability of a conditional sentence. Section 742.1 identifies several prerequisite criteria that must be fulfilled before a court may impose a conditional sentence, including the criterion that the court must be "satisfied that serving the sentence in the community would not endanger the safety of the community."22 The Supreme Court of Canada examined the conditional sentencing regime in detail in Proul $x$ and devised an innovative interpretation of the test of endangerment. It is necessary to review the Court's earlier decision in this respect in order to understand fully the significance of Knoblauch.

According to Proulx, assessing the danger that the offender poses to the community requires an examination of two components of dangerousness: (i) the probability of reoffending; (ii) the seriousness of any further offending in the event of reoffence. ${ }^{23}$ The relationship appears to be asymmetrical: if the magnitude of the risk is more than minimal, but the seriousness of subsequent offending is very low, then the offender may be eligible for a conditional sentence. ${ }^{24}$ The reverse is not the case: if the seriousness of future offending is likely to be great even if the risk of reoffending is minimal, a conditional sentence is inappropriate: "In certain cases, the minimal risk of re-offending [sic] will be offset by the possibility of a great prejudice, thereby precluding a conditional sentence."'s

The critical question is whether the optional conditions that may be imposed as part of a conditional sentence order can be considered when the court is evaluating the threat to the community posed by the offender. The dissent by Bastarache J. in Knoblauch implies that the test of danger to the community ends once the probability/seriousness of reoffending has been calculated. If the combination of risk of reoffending and consequences of the further offending is sufficiently serious, then there is no need to

22 Section 742.1(b).

23. Proulx, supra note 14 at para. 69.

24 This arrangement permits the persistent, but petty offender from being excluded from consideration for a conditional sentence.

25

Proulx, supra note 14 at para. 69. 
consider the conditional sentence any further: the offender has not passed the test of dangerousness.

This dissent appears to take direct issue with Proulx in this matter. Bastarache J. argues that it would be an example of circular reasoning to consider the nature of the conditions to be imposed as part of a conditional sentence order without having established the offender's eligibility for such a disposition in the first place:

When a sentencing judge is at the initial stage of determining whether a conditional sentence would be appropriate, he or she should not engage in a circular analysis by deciding first that the offender is dangerous but then searching for conditions which could be crafted to alleviate the danger. ${ }^{26}$

Thus there are two points central to the dissent: (a) that evaluation of the threat that the offender represents should precede discussion of the specific conditions that may be attached to a conditional sentence order in the event that one is eventually imposed, and (b) that if the gravity of any subsequent reoffending is high, then imposition of a conditional sentence is inappropriate, even if the probability of relapse is minimal. There would appear to be some support in Proulx for the latter point, ${ }^{27}$ none for the first.

Before examining the first point - whether consideration of conditions should accompany the court's evaluation of risk to the community - it is worth noting that there are other objections to the minority judgment's position that future offending, if it occurs, is likely to be of such a seriousness that even a minimal risk occurring renders the offender ineligible for a conditional sentence. First, it assumes that any future reoffending is likely to conform to previous offending both in nature and seriousness. Research in the area of recidivism and criminal careers refutes this notion of "specialization" in offending patterns. ${ }^{28}$ The nature of previous culpable conduct is seldom a reliable predictor of the nature or seriousness of future offending. ${ }^{29}$ Second, using the offender's previous conduct privileges the role of prediction: it permits the court to determine the nature and severity of the sanction by reference not to the seriousness of the offence of conviction, but by expert projections regarding the "risk" of reoffending. ${ }^{30}$ This runs counter to the principle

Knoblauch, supra note 1 at para. 113.

Proulx, supra note 14 at para. 69.

This research is summarized in J.V. Roberts, "The Role of Criminal Record in the Sentencing Process" in M. Tonry, ed., Crime and Justice: A Review of Research (Chicago: University of Chicago Press, 1997) vol. 22 at 303. See also R.K. Hanson \& M.T. Bussière, "Predicting Relapse: A MetaAnalysis of Sexual Offender Recidivism Studies" (1998) 66 Journal of Consulting and Clinical Psychology 348.

Nor is past offending necessarily a signpost to future offending; although national recidivism statistics are unavailable in Canada at present, the one recidivism study by Statistics Canada uncovered an aggregate recidivism rate of one third, which means that someone predicting future offending on the basis of past offending would be wrong twice as often as they would be right. See G. Campbell, An Examination of Recidivism in relation to Offence Histories and Offender Profiles (Ottawa: Canadian Centre for Justice Statistics, 1993).

K.S. Douglas \& C.D. Webster, "Predicting Violence in Mentally and Personality Disordered Individuals" in R. Roesch, S.D. Hart \& J.R.P. Ogloff, eds., Psychology and Law: The State of the Discipline (New York: Kluwer Academic, 1999) 175. 
of proportionality, which emphasizes the seriousness of the crime of conviction, and to a much lesser extent, the offender's criminal antecedents.

The majority in Knoblauch took a different view, which reflects a more integrated determination of danger to the community in light of the conditions likely to be imposed as part of the conditional sentence order. Writing for the majority, Arbour J. makes it clear that the nature of the conditional sentence that may be imposed plays a role in the determination of whether the offender is sufficiently dangerous to be denied consideration of a conditional sentence. Thus "if the conditions contemplated by the trial judge are taken into account in evaluating the risk that the appellant would re-offend while serving his conditional sentence, that risk is reduced to a point that is no greater than the risk that the appellant would re-offend while incarcerated in a penal institution." ${ }^{31}$

The majority's position seems both more reasonable and more consistent with the former Chief Justice's position with respect to this issue in Proulx. Arbour J. notes that

[1] the risk of re-offence should also be assessed in light of the conditions attached to the sentence. Where an offender might pose some risk of endangering the safety of the community, it is possible that this risk be reduced to a minimal one by the imposition of appropriate conditions to the sentence. ${ }^{32}$

This argument echoes the position in Proulx where the unanimous Court noted that

the risk of re-offence should also be assessed in light of the conditions attached to the sentence. Where an offender might pose some risk of endangering the safety of the community, it is possible that this risk be reduced to a minimal one by the imposition of appropriate conditions to the sentence. ${ }^{33}$

The Proulx judgment further notes that in resolving the issue of threat to the community

the focus of the analysis at this point should clearly be on the risk posed by the individual offender while serving his sentence in the community. ${ }^{34}$

This passage makes it crystal clear that the Court envisaged a determination of the probability (and severity) of reoffending by reference to the conditions of the sentence, and not before the sentence has begun to be served. The question is not whether the offender would pose a threat to the community if he walked out of the courthouse a free man. $^{35}$

Knoblauch, supra note 1 at para. 28.

Ibid. at para. 27 [emphasis added].

Proulx, supra note 14 at para. 72 [emphasis added].

Ibid. at para. 68 [emphasis added].

There is a clear, although not perfect analogy with the bail decision. Section 515(4) of the Criminal Code authorizes conditions to be imposed to ensure the safety of the community and the attendance of the accused. The decision to grant judicial interim release is not made without consideration of the likely effect of these conditions on the accused's compliance with the requirement to attend trial. 
If the concern is with the threat to the community as a result of the offender's future behaviour, there must be a consideration of the context in which that behaviour will emerge. Threat to the community cannot be established without a clear understanding of the conditions that will be placed on the offender and the effect that these conditions will have on the offender's conduct. ${ }^{36}$ Here too, the direction in Proulx is highly relevant: judges must have sound knowledge of the nature of supervisory arrangements: "A conditional sentence drafted in the abstract without knowledge of what actual supervision and institutions and programs are available and suitable for this offender is often worse than tokenism: it is a sham." ${ }^{37}$

By analogy, governments that license and regulate container ships cannot determine the danger to coastal waters simply by reference to the a priori toxicity of the cargo being transported. The threat must be evaluated in light of the nature of the vessel's protection against perforation, arrangements in place to ensure the safe dispersal of any effluents and, so forth. If dangerousness alone was determinative, potentially dangerous goods would never be transported. This analysis seems particularly appropriate to the threat to the community in the case of Knoblauch. The offender's dangerousness sprung from two sources: his ready access to an accumulation of explosive materials and his underlying mental disorder. Confined within a locked psychiatric facility, the appellant would be denied the former and treated for the latter. Confinement within a prison would achieve the incapacitation of the offender but would at best impair his treatment, and at worst deprive him of any effective treatment.

The statutory purpose underlying the optional conditions that may be imposed as part of a conditional sentence order makes a clear link between the nature of those conditions and the question of threat to the community. The threat to the community is of course the possibility of reoffending. Section 742.3(2) authorizes the court to impose a number of possible optional conditions, and contains a basket clause which permits the court to impose "such other reasonable conditions as the court considers desirable ... for securing the good conduct of the offender and for preventing a repetition by the offender of the same offence or the commission of other offences." ${ }^{38}$ Thus the optional conditions that may be imposed as part of a conditional sentence order are directed towards reducing the likelihood of recidivism that constitutes the threat to the community. ${ }^{39}$ This is in clear contrast to the optional conditions of a probation order that are directed towards "facilitating the offender's successful reintegration into the community."

Another adverse consequence of determining an offender's dangerousness before considering the nature of the conditions that may be imposed relates to the issue of electronic monitoring, which is rapidly assuming a greater role in the administration of

w.

It is worth noting that the testimony of the expert psychiatric witnesses was directed at the question of whether the offender was dangerous, not whether this level of threat could be safely contained within the context of a conditional sentence order. Proulx, supra note 14 at para. 73.

Section 742.3(2)(f).

For example, the imposition of a seven day-a-week curfew on the accused: $R$. v. Hames, [2000] A.J. No. 1538 (Q.B.), online: QL (AJ).

Section 732.1(3)(h). 
conditional sentences of imprisonment. If dangerousness is determined without a consideration of conditions such as electronically verified house arrest, this will deny conditional sentences to offenders who represent a level of risk manageable if electronic monitoring is ordered. Imposition of house arrest verifiable by electronic monitoring may reduce the risk posed by a particular offender to an acceptable level; consideration of a conditional sentence in such a case is ruled out if the threat to the community is considered in the abstract.

\section{ROLE OF THE JUdGE IN SENTENCE AdMinistration}

Including the conditions of any potential conditional sentence order in the evaluation of the threat to the community requires the court to have a sound grasp of the reality of sentence administration. Ordering an offender to serve the sentence in a particular facility only makes sense if any future changes to the facility or the treatment provided therein are brought to the subsequent attention of the sentencing judge. In this sense, the position taken by the majority is consistent with a tendency of some trial judges to become more involved in the administration of sentences, particularly those served in the community (such as a conditional sentence). Some courts will resist this additional burden upon their time and their resources; others will recognize (and may even welcome) the inevitability of becoming further implicated in sentence administration. ${ }^{41}$

At the present, a live concern for trial judges considering the imposition of a conditional sentence has been the ability of provincial correctional authorities to supervise adequately offenders serving conditional sentences. There is little point ordering a curfew or house arrest if the technology to monitor compliance or the requisite number of correctional sentence supervisors is not available. A national survey of judges conducted just prior to the Proulx judgment revealed that significant proportions of respondents were concerned about the question of conditional sentence administration. Four out of five judges surveyed stated that they would impose more conditional sentences if more supervisory resources were available. ${ }^{42}$ In addition, few of the judges surveyed were of the opinion that in their jurisdictions the number of treatment programs to support conditional sentences was adequate. By highlighting the importance of the conditions attached to a conditional sentence, the judgment in Proulx may well have stimulated greater efforts on the part of provincial correctional authorities to provide sufficient resources for the adequate supervision and monitoring of offenders serving terms of imprisonment in the community.

$\$$ Judicial interest in "blended" sentences, which conflate a term of custody with a period of conditional imprisonment, is evidence of the increased interest of some judges in the administration of sentences. Historically, of course. in Canada there has been a clear separation between the determination of sentence and the administration of the order.

$\therefore \quad$ See Department of Justice, Conditional Sentencing: Results from a National Survey of Judges by J.V. Roberts, A.N. Doob \& V. Marinos (Ottawa: Department of Justice Canada, 1999). 


\section{SHORT VERSUS LONG-TERM DANGER TO THE COMMUNITY}

Finally, it is important not to interpret the safety of the community in too narrow a sense. Consideration of further offending should not be restricted to the period in which the offender is under the jurisdiction of the court. In a case such as Knoblauch, one with a longer-term view of community would argue that the offender should receive treatment for an underlying mental disorder that has clearly played a causal role in the behaviour that has brought him before the court. There seems little doubt that two years in a psychiatric facility would be of greater therapeutic benefit than a comparable time in a correctional facility, subject to the possibility of temporary absences or conditional release on parole. Indeed, there is reason to believe that the time in custody would make matters worse and generate a greater threat to the community once the period of custody or the warrant of the court expires.

\section{Potential CONFlict WITH the PURPOSE AND PRINCIPLES OF SENTENCING}

Even if the offender's danger to the community can be managed within the context of a conditional sentence, the imposition of such a disposition must still be "consistent with the fundamental purpose and principles of sentencing set out in sections 718 to $718.2 . " 43$ It might be argued that by sending the offender to a treatment facility rather than a prison, the Court has allowed a utilitarian sentencing objective (rehabilitation) to take precedence over considerations such as desert and denunciation. This is not a question of allowing treatment to trump proportionality in sentencing, since the nature of the sentence - a conditional sentence of two years less a day followed by three years of probation, all of which may be served in a locked psychiatric institution - cannot be described as disproportionate to the offences of conviction. ${ }^{44}$

In this respect, the majority judgment reiterates one of the lessons of Proulx: A conditional sentence is made to conform to the purpose and principles of sentencing (which might otherwise be violated) through the imposition of conditions that have an important impact on the offender's liberty. The point is made repeatedly throughout Proulx: "conditional sentences should generally include punitive conditions that are restrictive of the offender's liberty. Conditions such as house arrest should be the norm, not the exception." ${ }^{45}$ There can be little doubt that up to five years in a locked psychiatric institution fulfils the need to restrict the offender's liberty.

One final note about proportionality is worth making. The dissenting judgment observes that

43. Section 742.1(b).

It It is perhaps important to bear in mind that the evidence to sustain the position that the offender constituted a threat to society rested not upon his current or previous offending, but rather on expert testimony. As noted by the majority in Knoblauch at para. 16: "There is no mechanism in criminal law to remove dangerous people from society merely in anticipation of the harm that they may cause. The limit of the reach of the criminal sanction is to address what offenders have done" [emphasis added]. Proulx, supra note 14 at para. 127. 
[t] he appellant was not found not criminally responsible by reason of mental disorder and. while conditional sentences were designed to permit the accused to avoid imprisonment. they were not designed to avoid punishment. The appellant possessed a culpable state of mind. Sentencing should reflect this. ${ }^{46}$

The sentencing process should nevertheless recognize the offender's diminished culpability, even if that falls short of exculpation. ${ }^{47}$

The position taken by the majority is not without some dangers. If a significant number of potentially dangerous offenders are sent to residential treatment facilities of various kinds and levels of security, there is the danger that the criminal justice system will lose some degree of control over individuals who have been found guilty of criminal behaviour. Trial judges will need to assure themselves that the conditions imposed - in part to punish and protect society - are not inappropriately modified by mental health professionals responsible for treating the offender. A court's responsibility to protect the community from reoffending may well be transferred to mental health professionals. Physicians and review boards or panels obviously do not apply the same criteria as parole boards when deciding whether to release the offender into the community or to a lower level of secure residential treatment.

That said, the court will presumably rely upon the consensual opinion of psychiatric experts. After all, in the absence of any serious criminal convictions (as was the situation in Knoblauch) it is the consensual opinions of experts that have guided the court's determination to confine the offender in one institution or another. If these experts assert special knowledge in relation to the assessment that a particular individual constitutes a risk to the community, then it may be presumed that they also possess a certain degree of expertise in relation to the task of determining when that same individual no longer poses such a risk. ${ }^{48}$

For these reasons, it might be advisable in such cases for the court to take a more active role in the administration of the sentence. This may involve ordering the offender to reappear at periodic intervals, rather than delegating the supervision to a conditional sentence supervisor. ${ }^{49}$ Perhaps important decisions regarding the offender's release or security arrangements need to be discussed in open court in front of the original sentencing judge. In the event that increased use of the conditional sentence diminishes the criminal justice budget by reducing provincial correctional costs, might not some of these savings be directed to generating more court time to permit such reviews?

Knoblauch, supra note 1 at para. 112.

See Schneider, supra note 2.

Douglas \& Webster, supra note 30. For a spirited critique of the use of risk assessment techniques by mental health professionals to justify the incapacitation of convicted offenders see T. Mathiesen, Prisons on Trial, 2d ed. (Winchester: Waterside Press, 2000) at 85-103, 183-189.

$\$ 4$

In R. v. Visanji, [1997] O.J. No. 2771 (Prov. Div.) online: QL (OJ), Cole J. ordered the accused to reappear in court "both in order that I may monitor their progress. and also as a salutary reminder of the need to comply with any and all conditions of their [sic] probation. I expect that I may well require them to make other appearances before me further along during their probation." 
The other danger created by the majority position in Knoblauch concerns a potential conflict between the goals of the penal system and those of the health care system. Detention in a secure custody facility achieves the goals of sentencing, and it will facilitate the treatment of the offender, which is the goal of medical professionals. However, the two systems may come into conflict if the therapeutic goal of healing requires the release of the offender at a stage earlier than would be consistent with the codified purpose and principles of sentencing. Moreover, while under a conditional sentence order, the offender may be ordered to attend treatment. What happens if he refuses, actively or passively, or if the therapeutic environment changes in a way that makes his continued presence undesirable? These are practical challenges that undoubtedly will arise in future cases.

In Knoblauch, it is important to bear in mind that the accused "overtly supported the proposed course of treatment" that he would receive in a locked mental health facility. ${ }^{50}$ Would it be appropriate to impose a conditional sentence where the accused does not consent to being sent to a locked psychiatric facility? In similar vein, was it significant that in Knoblauch the accused had been civilly committed prior to sentencing? Civil commitment imposes severe restrictions on the liberty of an individual and may involve the administration of involuntary treatment. Would the trial court have made use of the conditional sentence if the accused had not been certified? If civil commitment is an essential element in this type of conditional sentence, then the impact of Knoblauch may vary considerably from one province or territory to another.

Mental health legislation falls within the exclusive jurisdiction of the provinces and territories, and both the criteria for, and consequences of, civil commitment may vary considerably in different jurisdictions. For example, in some jurisdictions the civil commitment of an individual automatically exposes him or her to the possibility of the involuntary administration of treatment; ${ }^{51}$ whereas other jurisdictions may permit involuntary treatment only if the individual is first determined to be incompetent to make treatment decisions on his or her own behalf. ${ }^{52}$ Furthermore, some jurisdictions may also require that consent be obtained from a substitute decision-maker (e.g., a close relative) $:{ }^{53}$ this interposes third parties into the situation that may be created by a conditional sentence. Finally, mental health legislation in some jurisdictions now permits a form of "outpatient civil commitment," which requires an individual to take treatment as one of the conditions for being released back into the community. ${ }^{54}$ Would the possibility that a convicted offender might be released on terms of "outpatient civil commitment" affect the decision whether to impose a conditional sentence? Clearly, the

sul Knoblauch, supra note 1 at para. 9.

st See, for example, Mental Health Act, R.S.B.C. 1996, c. 288, s. 31. The constitutionality of the statute was affirmed by the British Columbia Supreme Court in McCorkell v. Riverview Hospilal (Director), [1993] B.C.J. No. 1518 (S.C.), online: QL (BCJ).

52 See, for example, Mental Health Act, S.A. 1988, c. M-13.1, Part 3; Hospitals Act, R.S.N.S. 1989 , c. 208 (as amended), s. 51; Health Care Consent Act, S.O. 1996, c. 2, Sch. A (as amended), s. 10. See, for example, Health Care Consent Act, S.O. 1996, c. 2, Sch. A (as amended), s. 20.

st See, for example, the introduction in 2000 of the "community treatment order" in Ontario (Mental Health Act. R.S.O. 1990 (as amended), c. M-7, s. 33.1] and the expanded use of the "on-leave" provisions of the Mental Health Act, R.S.B.C. 1996, c. 288 (s. 39). 
lack of uniformity in mental health legislation in the various provinces and territories may well result in quite different considerations being taken into account by sentencing judges who are contemplating the imposition of a Knoblauch type of conditional sentence.

To summarize the argument with respect to the test for dangerousness, it would seem unreasonable to come to a determination of the offender's threat to the community without considering the likelihood and severity of reoffending within the context of the conditions that would be attached to a conditional sentence order. This of course raises the question of what kinds of optional conditions (which might reduce the threat to the community to an acceptable level) are contemplated by the conditional sentencing regime, and this leads to the next point of contention: can a court order an offender to serve a conditional sentence in a locked psychiatric facility?

\section{B. Can Confinement in a locked Psychiatric Facility be a CONdition of a Conditional SENTENCE ORder?}

The principal dissenting opinion rejects the view that the optional conditions of a conditional sentence order empower the judge to order an offender to serve the sentence in a secure psychiatric institution. ${ }^{55}$ Several grounds are advanced by the minority to support this position, including the observation that a psychiatric institution is exactly that - an institution - and thereby no different from a correctional facility. The majority

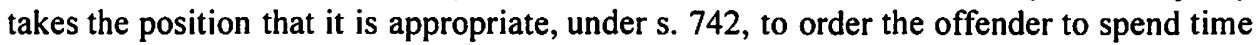
in a locked facility.

The answer to this question is clearly determinative of the response to the first. If the court cannot impose a secure confinement condition in this case, then there would appear to be no alternative to a term of correctional custody; a conditional sentence without a condition of secure detention would not provide the protection that addresses the threat to the community. Absent this condition, then, the offender cannot meet the low-risk threshold required for the imposition of a conditional sentence. Resolution of this question then is clearly related to the preceding question.

There is nothing in the language of s. 742.3 that delineates the kinds of optional conditions that are appropriate or inappropriate to attach to a conditional sentence order. Section 742.3(2)(f) orders the offender to comply with "other such reasonable conditions as the court considers desirable, subject to any regulations made under subsection 738(2), for securing the good conduct of the offender and for preventing a repetition by the offender of the same offence or the commission of other offences." Section 742.3(2)(e) authorizes the court to order the offender to "attend a treatment program approved by the province." There is no reason to believe that these sections preclude ordering an offender to participate in residential treatment programs approved by the province. 
The conditional sentence has been criticized for having too broad an application and for encompassing an excessively wide range of offence seriousness. ${ }^{56}$ Thus it has never been the case (despite the urgings of two interveners and the Crown appellants in Proulx) that the sanction is restricted to the least serious cases (so long as the statutory prerequisites are met). Indeed, one of the unmistakable messages of Proulx was that the new sanction should have a very broad application. This emerges from several passages, of which the following is a clear example:

No offences are excluded from the conditional sentencing regime except those with a minimum term of imprisonment, nor should there be presumptions in favour of or against a conditional sentence for specific offences. $^{57}$

If the sanction has a broad application to a wide range of offences and offenders, then it makes no sense to constrain the optional conditions that may be imposed by a court. Indeed, constraining the range of optional conditions would, of necessity, greatly restrict the range of application of the sanction itself. The breadth of the sanction's application must be matched by an equal diversity in terms of the optional conditions that serve to secure compliance, prevent reoffending, and promote subsequent restoration with the community. As noted by the majority in Knoblauch, "[t]he intent of s. 742.1 is to invite courts to draw on all available services in the community." 58

The phrase "all available services" must include residential as well as outpatient treatment, and secure as well as open treatment facilities. Otherwise judges would be invited to contemplate the imposition of a conditional sentence, and yet be deprived of the appropriate tools to ensure that the objectives of sentencing were achieved. If a court cannot order compliance with secure residential requirements, then the safety of the community cannot be assured, and the offender must be confined to a provincial correctional institution. One of the innovations in sentencing introduced by Bill C-4l was providing judges with the power to order treatment by means of the optional conditions attached to the conditional sentence order. There is no reason to believe that drafters of the legislation intended to put such an important restriction on the nature of the treatment that could be ordered by a sentencing judge.

There is a final reason why residential treatment, even in a locked facility, must be available to a sentencing judge constructing a conditional sentence. Without this option, many offenders who could benefit most from court-ordered treatment would be excluded. For many mental disorders and addictions the most effective treatment options are partially, primarily or exclusively residential in nature.

It is argued in the dissent that ordering the offender to serve a conditional sentence in a locked facility is tantamount to ordering custody as a condition of a conditional

W. Over 96 percent of custodial sentences imposed in provincial courts in 1998-99 were under two years less one day, the ceiling for imposition of a conditional sentence. See J.V. Roberts \& C. Grimes, "Adult Criminal Court Statistics, 1998/99" (2000) 20:I Juristat at Table 5.

ik Knoblauch, supra note 1 at para. 41 [emphasis added] 
sentence. The courts have generally rejected mixed or blended sentences according to which an offender spends part of the sentence in custody and part in the community as part of a conditional sentence order. The objection to a blended sentence is that it distorts the conditional disposition, which is meant to be an alternative to a prison sentence, not a more lenient conclusion to a custodial term.

The notion of blended sentences appears to have arisen earlier in the history of the conditional sentence, when there was some frustration among judges that the conditional sentence lacked "penal bite" and too closely resembled a term of probation. Inserting a custodial component was a way of "beefing up" the new disposition. However, that stage is now passed, in light of the clear direction from the Court in Proulx regarding the ways in which conditional sentences may be constructed so as to mark them clearly from sentences of probation. ${ }^{59}$ The relevance of the blended sentence analogy rests upon the assumption, examined in further detail later in this article, that a secure psychiatric institution is the equivalent of, and therefore no real substitute for, a term of imprisonment.

\section{Defining the Community in a Community-Based Sanction}

A related principal disagreement between Arbour J. for the majority and the dissent by Bastarache J. concerns the question of whether the concept of community envisaged by Parliament was intended to include a secure psychiatric facility. The majority position is that a psychiatric facility, even a secure one from which the individual may not leave of his or her own volition, is an alternative to imprisonment per se and, therefore, a legitimate location to which an offender on a conditional sentence order may be sent.

Bastarache J. takes the opposite view and appears to regard being confined in a locked psychiatric facility as an institutional sentence and, therefore, indistinguishable from correctional custody. The position of the minority is founded upon the notion of institutionalization and the degree of constraint imposed on residents. It should be noted that in Proulx, the Court observed that

offenders serving a conditional sentence in the community are only partially deprived of their freedom. Even if their liberty is restricted by the conditions attached to their sentence, they are not confined to an institution and they can continue to anend to their normal employment or educational endeavours. They are not deprived of their private life to the same extent. ${ }^{60}$

Can being ordered to serve a sentence in a secure facility such as a locked psychiatric ward be considered a community-based sanction? This question takes us back to the nature and original purpose underlying the creation of the conditional sentence of imprisonment.

The Court argued that punitive conditions such as house arrest should become the norm, that the length of the conditional sentence could extend beyond the term of custody that it replaces, and that there should be a presumption in favour of incarceration following an unjustified breach of conditions: see J.V. Roberts \& P. Healy, "The Future of Conditional Sentencing" (2001) 44 Crim. L.Q. 309.

(x) Proulx. supra note 14 at para. 40 
Although in practice a conditional sentence may not restrict an offender's lifestyle to the same extent as a term of custody, the degree of constraint is surely not what defines a conditional sentence and distinguishes it from a term of "conventional" imprisonment. If this were the case, a very intrusive conditional sentence, constructed so as to restrict the offender's freedom of action to an even greater extent than prison, would lose its status as a community-based sanction, even though the offender might continue to reside at home. Moreover, relying on the degree of constraint imposed in order to define a community sanction can only serve to undermine the utility of alternative sanctions such as conditional sentences as true replacements for imprisonment. In order to distinguish a conditional sentence from a term of custody served in a correctional institution we must look elsewhere, and the purpose underlying the creation of the new sanction may show us the way.

The conditional sentence was not created to lenify the sentencing process, although that may have been an unanticipated consequence. Rather, the aim was to hold offenders accountable for their offending without having to resort to the physical separation and stigmatization that invariably accompanies penal confinement. The purpose of prison is to isolate, punish, and latterly to rehabilitate. In contrast, the purpose of a secure psychiatric institution is to isolate, but also to heal. The isolation is necessary for the protection of the public; the treatment is appropriate (and necessary) because the offender is mentally disordered. At heart, then, the difference between a conditional sentence and a provincial prison term must surely lie in the concept of penal confinement. The latter consists of sequestration from society in an institution, the primary - some would say the exclusive - purpose of which is to punish.

When Parliament created an alternative sanction to incarceration, it was not contemplating simply a sanction that would impose fewer restrictions on offenders. Doing this would have been a very modest step indeed towards sentencing reform. The conditional sentence is surely something more significant; it is about holding offenders accountable for offending while respecting the statutory purpose and principles of sentencing, but without subjecting the offender to penal confinement.

According to this analysis, confinement in a psychiatric institution is an alternative to custody, for by the term "custody" we intend to connote penal confinement. Arguing that "confinement is confinement" overlooks the critical distinction between penal and nonpenal detention, between penal and non-penal hardships. Imposing a $\$ 500$ tax on a person visits the same degree of hardship as a $\$ 500$ fine, but the latter is qualitatively different: unlike a tax, the court-ordered fine connotes legal censure of the person fined. In fact, this analogy captures the essence of state-ordered punishment: hardship of some degree accompanied by penal censure. ${ }^{61}$ This view is clearly embraced by the majority judgment in Knoblauch, which states that "[t]he alternative to incarceration that Parliament

6) von Hirsch argues that the penal law performs two functions: "By threatening unpleasant consequences, it seeks to discourage criminal behaviour. Through the censure expressed by such sanctions, the law registers disapprobation of the behaviour. Citizens are thus provided with moral and not just prudential reasons for desistence." See A. von Hirsch, Censure and Sanctions (Oxford: Clarendon Press, 1993) at 12. 
contemplates is the alternative not to a particular place or building, but to a regime of detention, program and release, governed by legislation such as the Corrections and Conditional Release Act." 62 Thus the fact that confinement in a locked psychiatric institution, in the words of the minority, "shares many of the attributes of a custodial sentence," ${ }^{63}$ does not make it a custodial sentence any more than the conditional sentence is the equivalent of a term of probation simply because it shares many of the attributes of probation. ${ }^{64}$

\section{ROle OF Restorative Element in SENTENCING}

It has been argued elsewhere that the judgment in Proulx effectively created a new, hybrid sentence rather than an intermediate sanction. ${ }^{65}$ An intermediate sanction lies between probation and prison on a continuum of severity. A hybrid sanction contains elements of restoration and elements of punishment. As such it is particularly suited for offenders for whom restoration or rehabilitation are as important as denunciation and deterrence.

It is important not to lose track of an important element of the sentencing reforms introduced in 1996: restorative justice. The importance of restorative justice for the sentencing process was underlined in $R$. v. Gladue. ${ }^{66}$ The position of the majority in Knoblauch recognizes that restoration is important, even for a potentially dangerous offender. Restoration of the offender must be preceded by treatment of the disorder that has given rise to the criminal behaviour. There can be little expectation that this healing will take place in a prison setting. A logical sequence of propositions appears to emerge.

First, the purpose and principles of sentencing require a sentence of custody (otherwise the issue of conditional sentencing would never have arisen). Second, the court is required to give "serious consideration ... to the imposition of a conditional sentence in all cases where the first three statutory prerequisites are satisfied." a consideration for all offenders, including potentially dangerous ones. Fourth, restoration or reintegration for mentally disordered offenders, such as the appellant in this case, is only conceivable following treatment. Fifth, treatment is only possible within a therapeutic context, and the statutory context of a conditional sentence will only permit treatment in a venue that effectively guarantees that the safety of the community is not at risk. This

Knoblauch, supra note 1 at para. 37.

Ibid. at para. 98.

Section 718.2(e) of the Criminal Code directs judges to consider "all available sanctions other than imprisonment that are reasonable in the circumstances"; this seems to envisage alternatives to penal confinement, or a different construction would presumably have been employed.

See Roberts \& Healy, supra note 59, and also discussion in A. Manson, "The Conditional Sentence: A Canadian Approach to Sentencing Reform, or, Doing the Time-warp again" in Department of Justice, The Changing Face of Conditional Sentencing: Symposium Proceedings (Ottawa: Department of Justice Canada, 2000).

[1999] I S.C.R. 688.

Proulx, supra note 14 at para. 90 [emphasis in original]. 
analysis thereby permits the committal of the offender to a locked psychiatric institution for the duration of the conditional sentence order.

At the end of the day, the judgment in Knoblauch will be seen by some as the triumph of ends over means; a mentally disordered offender has been sentenced to a disposition that includes a strong treatment component. Critics may argue that the definition of a conditional sentence has been stretched beyond its original conception to accomplish this goal, that other routes exist by which an offender such as Mr. Knoblauch could have received treatment. Whether those other mechanisms are more appropriate is a complex question that needs to be addressed in another paper.

\section{E. EFFECTS OF KNOBLAUCH ON TRIAL JUDGES}

What effects is the Knoblauch judgment likely to have on trial judges? First, it may enlarge the range of offenders granted a conditional sentence by empowering judges to consider various residential (secure or otherwise) treatment facilities as potential locations to which offenders on a conditional sentence order may be sent. Drug offenders constitute an obvious population that may benefit from the majority's direction in Knoblauch. Many of these offenders constitute a high risk for reoffending, and their criminal behaviour springs largely from a need to finance their addiction. ${ }^{68}$

One of the features of a conditional sentence order that distinguishes the sanction from probation is that the court may order the offender to attend authorized treatment programs; ${ }^{69}$ the consent of the offender is required for treatment to form part of a probation order. ${ }^{70}$ This combination of treatment and punishment has already been implemented in drug treatment courts in the United States and in Canada's sole Drug Treatment Court (in Toronto). The combination may now be applied to drug offenders processed through conventional provincial courts, at least where the form of drug treatment includes a residential requirement.

As well, we might anticipate that some offenders hitherto regarded as having failed to satisfy the "danger to the community" test may henceforth be given greater consideration for a conditional sentence order. Since these kinds of offenders would previously have been consigned to a provincial correctional institution, it is possible that the number of mentally disordered offenders serving sentences in correctional facilities will decline.

If this actually happens, Knoblauch will have served an important purpose that will benefit both the correctional and therapeutic communities. The majority judgment begins by noting that "this appeal lies at the often ambiguous crossroads between the criminal justice and mental health care systems." "71 Those crossroads have until now been clogged

$\cos$

This is clear from very recent data collected from drug offenders in Toronto; see B. Fischer et al., "Illicit opiates and crime: Results of an untreated use cohort study in Toronto" (2001) 43 Can. J. Crim. 197.

Section 742.3(2)(e).

Section $732.1(3)(\mathrm{g})$.

Knoblaich, supra note I at para. 1. Perhaps the analogy of the roundabout or traffic circle is more apt; with offenders continually moving around the criminal justice system and mental health systems. 
with traffic carrying many seriously mentally disordered offenders to prison. However, the Knoblauch case may reduce the congestion by sending more cases in the opposite direction - towards mental health facilities. In the absence of a formal system of hospital orders, Canadian courts may well find that the conditional sentence is the vehicle of choice in cases where both the mental health and criminal justice systems have a role to play in responding to offenders. 